\title{
Assessment of Beneficiary Satisfaction with Community Based Solid Waste Management Service. A case of Okoa Maisha Project in Mnarani Village, Kilifi County, Kenya
}

\author{
Farida A. Hassan ${ }^{1 *}$, Hilda A. Ong'ayo ${ }^{1}$, Melckzedeck K. Osore ${ }^{2}$, George N. Morara ${ }^{3}$, Christopher M. \\ Aura $^{4}$ \\ ${ }^{1}$ Pwani University, P.O. Box 195 - 80108, Kilifi, Kenya \\ ${ }^{2}$ Kenya Marine and Fisheries Research Institute, P.O. Box 81651- 80100 Mombasa, Kenya \\ ${ }^{3}$ Kenya Marine and Fisheries Research Institute, P.O. Box 837 - 20117 Naivasha, Kenya \\ ${ }^{4}$ Kenya Marine and Fisheries Research Institute, P.O. Box 1881- 40100, Kisumu, Kenya
}

\begin{abstract}
Solid Waste Management Service (SWMS) is an important public good, although most local governments in developing countries have failed to effectively provide it to their populace. Ineffective SWMS has serious environmental and public health ramifications. Consequently, other players such as NonGovernmental Organizations (NGOs), private companies and Community Based Organizations (CBOs) have to be involved in the delivery of SWMS. This study assessed the level of beneficiary for households' satisfaction with SWMS as rendered by Okoa Maisha Project (OMP - the Swahili translation for project of saving lives) operating under the auspices of Where Talent Lives (WTL) - a local CBO located in Mnarani Village in Kilifi County in Kenya. The study revealed that majority of the respondents $(52.4 \%, n=152)$ were very satisfied with the overall SWMS as rendered by OMP. The satisfaction was mostly due to quality variables such as householders' education on solid waste management $(54 \%, n=157)$, neatness of waste collection crew $(52.4 \%, \mathrm{n}=152)$ and reliability of waste collection $(49.7 \%, \mathrm{n}=144)$. Relative to other indicators, the respondents ranked low quality variables such as frequency of waste collection from households and the behaviour of the waste collection crew towards the residents. The study concludes by emphasising on the need for assessment of SWMS as provided by CBOs for improved service delivery. The study recommends routine supervision of the SWMS rendered by donor or government sponsored projects for effective and sustainable service delivery to the beneficiary householders and the community
\end{abstract}

\section{Key Words}

Solid Waste Management Service (SWMS), Community Based Organizations (CBOs), Funded community projects, Kilifi County

\section{Introduction}

Municipal Solid Waste (MSW) also simply known as garbage or trash are wastes generated every day and comprise of paper, tin cans, bottles, clothes, glass, metals, e-wastes and hazardous wastes such as paint and aerosol spray (Bello et al., 2016). Every task, from preparing a meal to manufacturing a computer and so forth, is accompanied with production of waste material, which cannot be used further and need to be disposed of effectively (Awunyo, et al., 2013). All sectors are considered as sources of MSW, however, residential areas are the major contributors of wastes followed by markets and commercial areas respectively (Okot-Okumu \& Nyenje 2011). A case study of 4 towns in Kenya (Nairobi, Nakuru, Mombasa and Kisumu) shows that around $61 \%$ of the wastes produced comprise of residential wastes, followed by industrial and others such as hospitals and markets (Mbogoma and Nyakango, 2009). Similarly, in Uganda, residential garbage takes a portion of $52-80 \%$ of the weight of wastes produced, followed by markets, commercial sectors, industrial sectors and others (Bello, et al., 2016).

Solid Waste Management Service (SWMS) entails the collection, transportation, processing, recycling or 
disposal of waste materials (Egun, 2009). Although SWMS is an important public good, most municipalities in developing countries responsible for providing SWMS have failed to serve a large section of the population (Bolaane and Ali, 2004; Nema, 2009; Patel et al., 2011). In developing countries, MSW is not well managed because cities and municipalities cannot cope with the accelerated pace of waste production (Modak, 2010). Where the SWMS is provided, it is highly ineffective (Firdaus and Ahmad, 2010) as only $50-80 \%$ of refuse generated is collected (Medina, 2010). The World Development Report (2004) indicated that too often services fail poor people because they are inaccessible or when accessible they are dysfunctional, extremely low in technical quality and unresponsive to the needs of the clients.

In the poorest communities (many of which are in sub Saharan Africa), 80-90\% of wastes generated are not collected for safe disposal (Ogu, 2000). Disposal of solid waste receives less attention than its collection as about $90 \%$ of what is collected in cities ends up in open dumps (Cointreau, 2008), deposited on vacant land or burnt by residents at backyards (Addo et al., 2015). Insufficient collection and poor disposal practices generate serious human health related problems (Loboka et al., 2013). Refuse left to rot in the streets of residential areas attract insects and rodents which are associated with various diseases such as plague, cholera among others (Waweru and Kanda, 2012). Also solid waste causes extensive environmental degradation leading to soil and water pollution and emission of carcinogens and greenhouse gases that contribute to climate change (Ayanshola et al., 2015).

Various factors are responsible for the ineffective SWMS - regarded as one of the most challenging areas of modern environmental management (Egun, 2009). These factors include rapid urbanization, population growth coupled with the expansion of cities, poor urban planning and diminishing financial resources (Bolaane and Ali, 2004; Katusiimeh et al., 2012). The high expenditure incurred in waste collection and management is at the center of the problem of inefficient waste collection and poor waste management (Addo et al., 2015). Approximately $20-50 \%$ of overall municipal budget is allocated for waste management but still, waste collection is not fully covered (Bello et al., 2016).

Taking into consideration the various components of the budget, it becomes challenging for municipalities to devote huge sums of money solely to waste collection and management (Eawag, 2008). The cost issue has prompted municipalities in some developing nations to adopt cost-reduction programmes as well as conservation tenets of "reduce, reuse, and recycle" (Egun et al., 2016). This is being achieved through aggressive community education of consumers and producers on waste reduction methods, while institutions and businesses that could buy up discarded materials are facilitated to enhance recycling and reuse (Egun et al., 2016). In addition, lack of transparency, bad governance and the prevalence of corruption in most African countries are major problems militating against efficient SWM (Bello et al., 2016). As a result, governments struggle with the problems of high volumes of waste generated; the disposal technologies and costs involved in managing MSW (Rotich et al., 2005).

In many developing countries in Africa, the public sector took monopoly of providing solid waste management services in urban cities and this was largely blamed for the mess in SWM (Akaateba and Yakubu, 2013). In Kenya for example, the responsibility of managing solid waste is vested on the local authorities (now the County governments) where they collect and dispose the MSW in their areas of jurisdiction (Waweru and Kanda, 2012). However, the public sector was commonly reported to be constrained due to lack of managerial and technical capacity, cumbersome procurement procedures and inadequate financial resources (Longe et al, 2009; Obirih-Opareh and Post, 2002). As such, for close to two decades SWMS provided by the local authorities have been on the decline (Muniafu and Otiato, 2010) prompting the entry of other players such as Non-Governmental Organizations (NGOs), Community Based Organizations (CBOs) and private companies (Waweru and Kanda, 2012). The involvement of other players besides the local authorities in provision of SWMS was further strengthened by the World Bank through its emphasis on a paradigm shift from a dominance of the public sector to inclusion of private sector in provision of public services. This strategy, which encouraged private sector participation, private-public sector partnerships and involvement of NGOs, communities and households, was later adopted as a global policy in the housing sector of the Global Strategy for Shelter in the Year 2000 (Ogu, 2000). 
Consequently, many CBOs are involved in the provision of SWMS in which they mainly focus on the less privileged urban communities serving more than half the population compared to urban councils and private companies combined (Okumu, 2012). The community-based approach includes systems managed at community level by CBOs or individuals that involve beneficiaries and refuse collectors as main actors. Community participation can comprise varying degrees of involvement by the local community that range from contribution of cash and labour to consultation, adaptation of behaviour, participation in administration, management and decision-making (Chinasho, 2015). It is expected that such communitybased services will not only fill the gap in service provision left by overburdened municipal authorities but will even become accepted as an integral component of the whole municipal waste management system (Muller et al., 2002). Case studies show that motivated individuals and community-based organizations (CBOs) can successfully setup and manage waste-collection systems that facilitate improvement of overall environmental concerns (Ahsan et al., 2012; Colon and Fawcett, 2006). Others believe that community participation in solid waste management is always required, because solid waste management is a continuous maintenance system. For instance, to store the garbage in a designated bag or bin, to bring it to an agreed collection point, to separate it in dry and wet waste, community participation is necessary (Gotame, 2012). While little attention is given to the potential of small-scale, private operators and CBOs removing solid waste informally from residential areas (Baud et al., 2001), it is believed that the effectiveness and efficiency of SWMS depends on the willingness and active participation of community members, as the waste is generated mainly from the local community (Chinasho, 2015).

In Kenya today, it is now common practice for CBOs to engage in provision of SWMS. As a result of this increased involvement of the CBOs in provision of SWMS, studies on the quality and efficiency of SWMS delivered by the private sector are becoming common (Akaateba and Yakubu, 2013). Various attempts have been made to assess the performance of private agencies vis-a-vis public agencies in waste management in developing countries (Massoud et al., 2003; Kassim and Ali, 2006; Baud et al., 2001; Kasseva and Mbulingwe, 2005; Obirih-Opareh and Post, 2003; Longe et al., 2009). These studies devised various indicator systems and instruments to measure the quality of waste management services delivered to residents (Akaateba and Yakubu, 2013). Baud et al. (2001) used a 9-point indicator system combining ecological, economic, social and public health concerns to assess how alliances between the public and private sector in solid waste management contribute to sustainable development. Akaateba and Yakubu (2013) used 12 indicators (see Table 1) to measures customers' satisfaction with SWMS.

Table 1: Indicators for measuring customer satisfaction with solid waste management service

\begin{tabular}{ll}
\hline No. & Indicators \\
\hline 1 & Frequency of waste collection from household \\
2 & Reliability of waste collection \\
3 & Prompt response to user complains \\
4 & Vehicles and equipment used to collect and dispose waste \\
5 & Final disposal site where vehicles dispose waste \\
6 & Cleanliness of service area \\
7 & Behavior/attitude of collection crew towards residents \\
8 & Neatness of waste collection crew, wearing of protective clothing \\
9 & Household education on waste management \\
10 & Overall service deliver \\
11 & Handling of waste containers during transportation \\
12 & Public monitoring and sanctioning by the Municipal Assembly \\
\hline
\end{tabular}

Source: Akaateba and Yakubu (2013) 
This study evaluated the performance of a community based SWMS implemented by OMP in Mnarani Village under the auspices of Where Talent Lives (WTL). Mnarani Village is located in Kilifi County - one of the six coastal counties forming the coastal region of Kenya. Being in close proximity to Kilifi Town, Mnarani has experienced an increase in population as people from various parts of the country migrate to the area to establish business and seek employment opportunities. This has accelerated generation of solid waste beyond the management capacity of the Kilifi County Government. As a result, a group of youths organized in the form of a CBO - "Where Talent Lives" formed OMP in 2007 with the sole objective of addressing the challenge of environmental degradation due to poor solid waste management. The youths held workshops to mobilize and sensitize the entire community on the importance of an effective SWMS for environmental protection and public health. Key stakeholders such as religious leaders, local administrators and local government officials were also invited to the workshops to get their buy in.

OMP was implemented with funding from Hazina Ya Maendeleo Ya Pwani (HMP), a community development grant mechanism under the Kenya Coastal Development Project (KCDP) - a multi-sectoral project financed by the World Bank. HMP provided grants to CBOs to undertake projects on community service and natural resource management projects that are of public good (Hassan et al., 2017; Aura et al., 2015). OMP started by serving a total of 300 households and later expanded to 800 - almost thrice the original capacity. The system of waste collection is mainly conducted from door-to-door and handcarts are used to ferry waste to a central collection point from where lorries from the County Government of Kilifi pick it to the final waste disposal site. To protect the waste collectors from injuries and direct contact with pathogenic organisms, protective gears such as gloves, boots, and overalls are worn. Household solid waste is collected twice a week at a fee of USD 0.5 per collection.

This study therefore assessed householders' level of satisfaction with solid waste collection services delivered by OMP. The study adopts the first 10 of the 12 indicators (Table 1) to measure the level of household satisfaction with SWMS provided by OMP.

\section{Methodology}

\section{Study area}

Mnarani Village is located in Kilifi County - one of the six counties forming the coastal region of Kenya. The village is made up of private homes and small businesses with a cosmopolitan population comprising coastal and upcountry tribes. The population of Mnarani is estimated at 9,000 persons (GoK, 2009).

Study Population

The target population in this study are the 9,000 people living Mnarani Village while the accessible population are the 800 householders currently being served by OMP

Sample Size

A sampling size $(\mathrm{N})$ of 384 persons was calculated using the equation adopted from Mugenda and Mugenda (1999) which is $\mathrm{N}=\mathrm{z} 2 \mathrm{pq} / \mathrm{d}^{2}$

Where $\mathrm{N}=$ the desired sample size (if target population is greater than 10000)

$\mathrm{Z}=$ the standard normal deviation at the required confidence level (in this case 1.96)

$\mathrm{p}=$ the proportion in the target population estimated to have characteristics being measured which is 0.50 .

$\mathrm{q}=1-\mathrm{p}$ and $\mathrm{d}=$ the level of statistical significance set which is 0.05 .

Since the target population was below 10,000 , the final sample size (nf) was then calculated as follows: $\mathrm{nf}=\mathrm{n} \div\left\{1+\frac{(\mathrm{n})}{(\mathrm{N})}\right\}$

Where; $\mathrm{nf}=$ desired sample size (when target population is less than 10,000);

$\mathrm{n}=$ desired sample size (when target population is greater than 10,000);

$\mathrm{N}=$ the desired sample size (target population). Therefore, $\mathrm{nf}=384 \div\left\{1+\frac{(384)}{(800)}\right\}=259.5$

Adjusting for non-response rate at 10\% gave a required sample size of 286, which was approximated to 290. Systematic random sampling method was used to select respondents. The approximate target population of 800 households was divided by the required sample size, 290 to get the sampling interval of 3 . The first household was selected at random and every 4th household was interviewed until the total number of 290 
households was reached.

A semi structure questionnaire was used to collect data from respondents. The first section of the questionnaire gathered socio-demographic and economic data of the respondents, which included gender, age, level of education, household size and economic activity. In the second section, the beneficiary householders were asked to assess the extent to which they were satisfied with SWMS by responding to the 10 statement touching on quality variables.

\section{Data Collection and Analysis}

Data gathered was processed and analyzed using the Statistical Package for Social Sciences (IBM-SPSS Inc. version 20.0). Descriptive statistics (frequency, percentages, mean and standard deviation) were largely used for the analysis. Data on respondents' feedback on each of the 10 statements analyzed using a Likert scale. A mean range of above 4 was considered "high satisfaction" while a mean of below 3 was considered to indicate "dissatisfaction". The study also used a Chi-square test to investigate differences among householders' level of satisfaction based on their education level.

\section{Results and Discussion}

\section{Socio-economic and demographic characteristics of respondents}

Majority $(54 \% ; n=157)$ of the respondents were females, while $46 \%(\mathrm{n}=133)$ were males (Table 2). The results show that due to their caretaker role women are more concerned with issues of SWM than men. This is in agreement with the assertion by Ezebilao and Animassan (2011) who noted that women are often the first to be hit by the waste disposal problems if SWMS is ineffective. This could be one of the reasons women participate more in recycling products than men do (Muderrisoglu and Altanlar, 2011). Majority $(43.4 \%, \mathrm{n}=126)$ of the respondents fell within the age group of $20-30$ years, an additional $35.2 \%(\mathrm{n}=102)$ of the respondents were within the ages of $31-50$ years and only $13.4 \%(\mathrm{n}=39)$ were below 20 years. The educational attainments of respondents were relatively high as $20.3 \%(\mathrm{n}=59)$ and $30.7 \%(\mathrm{n}=89)$ of the respondents had attained university and college education respectively. Only $14.1 \%(\mathrm{n}=41)$ of the respondents had primary level education. In terms of household sizes, majority $(31.7 \%, \mathrm{n}=92)$ of the respondents had large households of $10-15$ persons while $25.5 \%(n=74)$ had household size of $6-10$ persons. Very few respondents $(18.6 \%, \mathrm{n}=54)$ had household sizes of $1-5$ persons. The study further revealed that majority $(42.1 \%, \mathrm{n}=122)$ of the respondents were employed. This correlates well with the findings on educational status where most of the respondents had attained college and university education. About 35\% $(n=100)$ of the respondents were engaged in various businesses while only $8.6 \%(n=25)$ undertook farming for their livelihood. This shows that Mnarani Village being close to an urban centre (Kilifi Town) makes farming a less feasible livelihood option. 
Table 2: Socio-economic characteristics of respondents

\begin{tabular}{|c|c|c|}
\hline Characteristic & Frequency (n) & Percentage (\%) \\
\hline \multicolumn{3}{|l|}{ Gender } \\
\hline Female & 157 & 54 \\
\hline Male & 133 & 46 \\
\hline \multicolumn{3}{|l|}{ Age } \\
\hline$<20$ Years & 39 & 13.4 \\
\hline $20-30$ Years & 126 & 43.4 \\
\hline $31-50$ Years & 102 & 35.2 \\
\hline$>50$ Years & 23 & 7.9 \\
\hline \multicolumn{3}{|l|}{ Education Level } \\
\hline Primary & 41 & 14.1 \\
\hline High School & 89 & 30.7 \\
\hline College & 101 & 34.8 \\
\hline University & 59 & 20.3 \\
\hline \multicolumn{3}{|l|}{ Household Size } \\
\hline 1-5 Persons & 54 & 18.6 \\
\hline $6-10$ Persons & 74 & 25.5 \\
\hline $10-15$ Persons & 92 & 31.7 \\
\hline Over 15 Persons & 70 & 24.1 \\
\hline \multicolumn{3}{|c|}{ Economic Activity } \\
\hline Farming & 25 & 8.6 \\
\hline Fishing & 37 & 12.8 \\
\hline Trading & 100 & 34.5 \\
\hline Employment & 122 & 42.1 \\
\hline Others & 6 & 2.1 \\
\hline
\end{tabular}

Source: Field Survey, 2018.

\section{Beneficiary householders level of satisfaction with SWMS}

The study assessed the extent to which householders are satisfied with SWMS provided by OMP by using a set of 10 quality variables responding to the question: To what extent are you satisfied with the SWMS rendered by OMP? Data on respondents feedback on each of the 10 statements were entered in SPSS as $5=$ very satisfied to $1=$ very dissatisfied. The level of satisfaction was calculated by computing and ranking the mean of their responses for each of the 10 statements. The results are presented in Tables 3 and 4 .

Table 3: Extent to which householders are satisfied with waste collection services

\begin{tabular}{|c|c|c|c|c|c|}
\hline $\begin{array}{l}\text { Statement: To what extent } \\
\text { are you satisfied with the } \\
\text { solid waste management } \\
\text { services rendered by } O M P\end{array}$ & $\begin{array}{c}\text { Very } \\
\text { Dissatisfi } \\
\text { ed } \\
\text { n }(\%)\end{array}$ & $\begin{array}{c}\text { Not } \\
\text { Satisfied } \\
\text { n }(\%)\end{array}$ & $\begin{array}{c}\text { Not } \\
\text { Sure } \\
\text { n }(\%)\end{array}$ & $\begin{array}{c}\text { Satisfied } \\
\text { n }(\%)\end{array}$ & $\begin{array}{c}\text { Very } \\
\text { Satisfied } \\
\mathbf{n}(\%)\end{array}$ \\
\hline $\begin{array}{l}\text { 1. Frequency of Waste } \\
\text { Collection }\end{array}$ & $7(2.4)$ & $6(2.1)$ & $3(1.0)$ & $173(59.7)$ & $101(34.8)$ \\
\hline $\begin{array}{l}\text { 2. Reliability of Waste } \\
\text { Collection }\end{array}$ & $3(1.0)$ & $9(3.1)$ & $0(0)$ & $134(46.2)$ & $144(49.7)$ \\
\hline 3. Prompt Response to User & $5(1.7)$ & $11(3.8)$ & $1(3)$ & $131(45.2)$ & $142(49.0)$ \\
\hline
\end{tabular}




\begin{tabular}{|c|c|c|c|c|c|}
\hline Complaints & & & & & \\
\hline $\begin{array}{l}\text { 4. Vehicles and Equipment Used } \\
\text { to Collect and Dispose Waste }\end{array}$ & $6(2.1)$ & $12(4.1)$ & $2(0.7)$ & $127(43.8)$ & $143(49.3)$ \\
\hline $\begin{array}{l}\text { 5. Final Disposal Site Where } \\
\text { Vehicles Dispose Waste }\end{array}$ & $3(1.0)$ & $12(4.1)$ & $1(0.3)$ & $127(43.8)$ & $147(50.7)$ \\
\hline 6. Cleanliness of Service Area & $5(1.7)$ & $12(4.1)$ & $2(0.7)$ & $122(42.1)$ & $149(51.4)$ \\
\hline $\begin{array}{l}\text { 7. Behaviour/Attitude of Service } \\
\text { Crew }\end{array}$ & $10(3.4)$ & $18(6.2)$ & $0(0)$ & $115(39.7)$ & $147(50.7)$ \\
\hline $\begin{array}{l}\text { 8. Neatness of Waste Collection } \\
\text { Crew towards Residents }\end{array}$ & $3(1)$ & $12(4.1)$ & $3(1.0)$ & $120(41.4)$ & $152(52.4)$ \\
\hline $\begin{array}{l}\text { 9. Household Education on } \\
\text { Waste Management }\end{array}$ & $7(2.4)$ & $9(3.1)$ & $2(0,7)$ & 115 (39.7) & $157(54,1)$ \\
\hline 10. Overall Service Delivery & $9(3.1)$ & $7(2.4)$ & $5(1.7)$ & $117(40.3)$ & $152(52.4)$ \\
\hline
\end{tabular}

Majority (52.4\%, n-152) of the householders in Mnarani Village were very satisfied with the overall service delivery by OMP (Table 3). About 40.3\% ( $n=117)$ of the respondents indicated that they were satisfied with the overall service delivery. The findings are consistent with those of Akaateba and Yakubu (2013) and Katusiimeh et al. (2012) who opined that householders are usually satisfied with the services provided by private waste collection firms. Similar results have been reported by Anestina et al. (2014) that $56 \%$ of users in low income areas and around $61 \%$ of users in high income area in Nigeria appear to be satisfied with the current quality of service provided by the domestic solid waste private service providers. The results are however contrary to those of Awortwi (2004); Ezebilo and Animasaun (2011) and Longe et al. (2009) that most residents were dissatisfied with SWMS provided by the private sector. Very few respondents (3\%) indicated that they were very dissatisfied with the overall SWMS as rendered by OMP. The findings concur with those of Ezebilo and Animasaun (2011) that most of the respondents were not satisfied with private participation in SWM in Ilorin, Southwest Nigeria.

Table 4: Householder's level of satisfaction in Mnarani Village

\begin{tabular}{|l|c|c|}
\hline $\begin{array}{l}\text { Statement: To what extent are you satisfied } \\
\text { with the solid waste management services } \\
\text { rendered by OMP }\end{array}$ & $\begin{array}{l}\text { Mean \& } \\
\text { Standard } \\
\text { Deviation }\end{array}$ & Rank \\
\hline Frequency of Waste Collection & $4.22 \pm 0.78$ & 7 \\
\hline Reliability of Waste Collection & $4.40 \pm 0.74$ & $1^{\mathrm{a}}$ \\
\hline Prompt Response to User Complaints & $4.36 \pm 0.82$ & $4^{\mathrm{a}}$ \\
\hline $\begin{array}{l}\text { Vehicles and Equipment Used to Collect and } \\
\text { Dispose Waste }\end{array}$ & $4.34 \pm 0.86$ & $5^{\mathrm{a}}$ \\
\hline $\begin{array}{l}\text { Final Disposal Site Where Vehicles Dispose } \\
\text { Waste }\end{array}$ & $4.39 \pm 0.79$ & $2^{\mathrm{a}}$ \\
\hline Cleanliness of Service Area & $4.37 \pm 0.84$ & $3^{\mathrm{a}}$ \\
\hline Behaviour/Attitude of Service Crew & $4.28 \pm 0.99$ & 6 \\
\hline $\begin{array}{l}\text { Neatness of Waste Collection Crew towards } \\
\text { Residents }\end{array}$ & $4.40 \pm 0.80$ & $1^{\mathrm{a}}$ \\
\hline Household Education on Waste Management & $4.40 \pm 0.86$ & $1^{\mathrm{a}}$ \\
\hline Overall Service Delivery & $4.37 \pm 0.89$ & $3^{\mathrm{a}}$ \\
\hline
\end{tabular}

Likert scale scores: 1= Very Dissatisfied; 5 Very Satisfied. a the first five highest ranking statements

The results indicate that the respondents were satisfied with all the quality variables of SWMS as rendered by OMP (Table 4). Some of the quality variables such as reliability of waste collection, neatness of waste collection crew and householders' education on solid waste management had the highest mean scores. The respondents also reported high levels of satisfaction with variables such as the final disposal site where 
vehicles dispose waste, cleanliness of service area, prompt response to user complaints and satisfaction with the vehicles and equipment used to collect and dispose waste. The results contradict those of Akaateba and Yakubu (2013) where householders were dissatisfied by variables such as final disposal site, prompt response to user complains, and household education on waste management.

The householders ranked relatively low variables such as the behaviour of the waste collection crew towards the residents and the frequency of waste collection from households. Similar results were reported by Anestina et al. (2014) that 44\% of users in low income area, 55\% in medium income area, and $18 \%$ in high income area of Lagos, Nigeria were not satisfied with low frequency of waste collection. This shows that the beneficiary householders would prefer to be treated well by the waste collection crew. The residents would also appreciate that the current twice a week frequency of waste collection services in the area is increased. While the results show a great level of beneficiary householder satisfaction with SWMS as rendered by OMP, the need for routine supervision of the SWMS to ensure effective service delivery cannot be overlooked. This argument concurs with the thinking of Ezebilo and Animasaun (2011) who indicated that although involvement of private sector in waste management can help to increase efficiency and effectiveness, it requires an organized public institution to monitor their activities. Awortwi (2004) cautions that merely shifting public services to the private sector will not in itself guarantee service quality and effectiveness. As such without routine supervision, the effectiveness of the SWMS may not be guaranteed. In the case of Mnarani, the supervision would be best provided by the Public Health Department of the Kilifi County Government.

\section{Householder satisfaction by education level}

The study also examined the relationship between the level of education and householders' level of satisfaction with the SWMS. Respondents were asked: To what extent are you satisfied with the SWMS rendered by $O M P$. The results are presented in Table 5.

Table 5: A Chi-square test between education level and householders' satisfaction with SWMS

\begin{tabular}{|l|c|c|c|c|c|}
\hline \multirow{2}{*}{$\begin{array}{l}\text { Statement: To what extent are } \\
\text { you satisfied with the solid } \\
\text { waste management services } \\
\text { rendered by OMP }\end{array}$} & \multicolumn{4}{|c|}{ Educational Level of Respondents } & \\
\cline { 2 - 5 } & Primary & $\begin{array}{c}\text { High } \\
\text { School }\end{array}$ & College & University & $p$ \\
\hline $\begin{array}{l}\text { 1. Frequency of Waste } \\
\text { Collection }\end{array}$ & 4.20 & 4.27 & 4.21 & 4.20 & 0.884 \\
\hline $\begin{array}{l}\text { 2. Reliability of Waste } \\
\text { Collection }\end{array}$ & 4.44 & 4.44 & 4.33 & 4.46 & 0.647 \\
\hline $\begin{array}{l}\text { 3. Prompt Response to User } \\
\text { Complains }\end{array}$ & 4.32 & 4.37 & 4.31 & 4.46 & 0.526 \\
\hline $\begin{array}{l}\text { 4. Vehicles and Equipment } \\
\text { Used to Collect and Dispose } \\
\text { Waste }\end{array}$ & 4.49 & 4.18 & 4.42 & 4.36 & 0.664 \\
\hline $\begin{array}{l}\text { 5. Final Disposal Site Where } \\
\text { Vehicles Dispose Waste }\end{array}$ & 4.46 & 4.44 & 4.35 & 4.34 & 0.812 \\
\hline 6. Cleanliness of Service Crew & 4.27 & 4.37 & 4.35 & 4.49 & 0.316 \\
\hline $\begin{array}{l}\text { 7. Behavior/attitude of Service } \\
\text { Crew Towards Residents }\end{array}$ & 3.98 & 44.38 & 4.19 & 4.49 & 0.093 \\
\hline $\begin{array}{l}\text { 8. Neatness of Waste } \\
\text { Collection Crew }\end{array}$ & 4.49 & 4.49 & 4.37 & 4.25 & 0.476 \\
\hline $\begin{array}{l}\text { 9. Household Education on } \\
\text { Waste Management }\end{array}$ & 4.46 & 4.29 & 4.46 & 4.42 & 0.572 \\
\hline 10. Overall Service Delivery & 4.49 & 4.26 & 4.26 & 4.63 & 0.270 \\
\hline
\end{tabular}


There was no significant difference $(\mathrm{p}>0.05)$ between educational level and householders' satisfaction across all quality variables of waste SWMS.

\section{Conclusion and Recommendation}

The study has demonstrated that overall, the beneficiary householders are very satisfied with the SWMS as rendered by OMP. Majority of the respondents (52.4\%) indicated that they were very satisfied while $40.3 \%$ of the respondents indicated that they were satisfied with the SWMS provided by OMP. Satisfaction of the beneficiary householders was due to quality aspects such as reliability of waste collection, neatness of waste collection crew and householders education on solid waste management that were ranked highly by the respondents. The respondents also reported higher levels of satisfaction with quality variables such as final disposal site where vehicles dispose waste, cleanliness of service area, prompt response to user complaints and satisfaction with the vehicles and equipment used to collect and dispose waste. Quality variables that were ranked relatively low (Table 4) include frequency of waste collection from households, and the behaviour/attitude of the waste collection crew towards the residents.

The study concludes by emphasising on the need for assessment of SWMS as provided by CBOs for improved service delivery. The study recommends routine supervision of the SWMS rendered by donor or government sponsored projects for effective and sustainable service delivery to the beneficiary householders. The supervisory role can be played by the respective department of the County Government.

Given the role played by CBOs in the management of MSW in many developing nations, this study has highlighted the relevance of assessing donor funded waste management systems for improved service delivery. Results from this study also provide useful new knowledge about user perception with regard to the community-based approach in the management of solid waste. This knowledge will no doubt contribute towards the improvement of SWM especially in areas neighbouring Kilifi County that share similarity in the socio-cultural context.

\section{Acknowledgement}

We acknowledge the Chief Executive Officer of OMP Mr. Ramadhan Ndiga and his entire team for providing information used in this study. We also wish to thank HMP team members and all the residents of Mnarani Village for accepting to participate and contribute in this study.

\section{References}

[1] Addo L. B., Adei, D., and Acheampong, E.O., (2015) Solid Waste Management and Its Health Implications on the Dwellers of Kumasi Metropolis, Ghana

[2] Ahsan, A., Alamgir, M., Imteaz, M., (2012) Role of NGOs and CBOs in waste management. Iranian Journal of Public Health 41: 27-38.

[3] Akaateba, A. M., and Yakubu, I., (2013) Householders' Satisfaction Towards Solid Waste Collection Services Of Zoomlion Ghana Ltd In Wa, Ghana. European Scientific Journal November 2013 edition vol.9, No.32 ISSN: 1857 - 7881 (Print) e - ISSN 1857- 7431.

[4] Alhassan H., Kwakwa, P. A., 2014 When water is scarce: the perception of water quality and effects on the vulnerable. Journal of Water, Sanitation and Hygiene for Development. 04-1 : 43-50

[5] Anestina,A. I.., Adetola, A.. and Odafe, I. B., 2014. Performance Assessment of Solid Waste Management following Private Partnership Operations in Lagos State, Nigeria. Journal of Waste Management Volume 2014, Article ID 868072, 8 pages http://dx.doi.org/10.1155/2014/868072

[6] Awortwi, N., (2004) Getting the fundamentals wrong: woes of public private partnerships in solid waste collection in three Ghanaian cities. Public administration dev. Vol 24 pp213-224

[7] Awunyo-Vitor, D., Ishak, S., and Seidu, J. G., (2013) Urban Households' Willingness to Pay for Improved Solid Waste Disposal Services in Kumasi Metropolis, Ghana. Urban Studies Research, 2013.

[8] Ayanshola, A. M., Aremu, A. S., Jacob, S.O., Bilevu, S. O. and Salami, A.W., (2015) Evaluation of Municipal Solid Waste Management System and Willingness to Pay for its Improvement in Ilotin, Kwara State, Nigeria State.

[9] Bello, I. A., Ismail M. N. B., Kabbashi N, A., (2016) Solid Waste Management in Africa: A Review. 
Int J Waste Resource 6: 216. doi: 10.4172/2252-5211.1000216

[10] Bolaane, B., and Ali, M., (2004) "Sampling Household Waste at Source: Lessons Learnt in Gaborrone." Waste Management \& Research 22, (3): pp 142-148

[11] Chinasho A., 2015 Review on community based municipal solid waste management and its implication for climate change mitigation

[12] Cointreau, S., 2008. Methane-2-MarketsFund: The Solid Waste Context of Developing Countries. The World Bank, Washington, DC.

[13] Colon, M., and Fawcett, B. (2006) Community-based household waste management: Lessons learnt from EXNORA's 'zero waste management' scheme in two South Indian cities. Habitat International 30: 916-931

[14] Daniel, H, and Perinaz, B.T. (2012) What a Waste - A Global Review of Solid Waste Management.

[15] Egun, N. K, Iniaghe, O.P., and Evbayiro, O.J. (2016) Assessment of landfill sites for solid waste management in Delta state, Nigeria. Journal of Environment and Waste Management 3(1): 116-122

[16] Egun, N.K. (2009). Assessment on the level of Recycling and Waste Management in Delta State, Nigeria. Journal of Human Ecology.27 (2): 77 - 82.

[17] Ezebilo, E. E., and Animasaun, E. D., (2011) Households' perceptions of private sector municipal solid waste management services: A binary choice analysis. J. Environ. Sci. Tech., 8 (4), 677-686

[18] Firdaus, G., and Ahmad, A., (2010) Management of urban solid waste pollution in developing countries. Int. J. Environ. Res., 4(4): 795-806.

[19] Government of Kenya (2009) Kenya National Census. Government Printer, Nairobi

[20] James Okot-Okumu, 2012 Solid Waste Management in African Cities - East Africa

[21] Katusiimeh, M.W., Mol, A.P.J., and Burger, K. (2012) The operations and effectiveness of public and private provision of solid waste collection services in Kampala. Habitat International 36: 247-252

[22] Leton, T, and Omotosho, O.,(2004) Landfill operations in the Niger Delta region of Nigeria. Eng Geol 73: 171-177.

[23] Leton, T., Omotosho, O. (2004) Landfill operations in the Niger delta region of Nigeria. Eng Geol 73 : 171-177.

[24] Liyala C.M., (2011) Modernizing Solid Waste Management at Municipal Level: Institutional arrangements in urban centres of East Africa. PhD Thesis. Environmental Policy Series. Wageningen University. The Netherlands.

[25] Loboka, M.K., Shihua, Q.,. Celestino, J. L., Hassan, S.O., and Wani S., (2013) Municipal solid waste management practices and fecal coliform water contamination in the cities of the developing countries: The case of Juba, South Sudan. Int. J. Environ. Sci., 3(5): 1614-1624.

[26] Longe, E. O.; Longe, O. O.; Ukpebor, E. F., (2009) People's perception on household solid waste management in Ojo Local Government Area in Nigeria. Iran. J. Environ. Health. Sci. Eng., 6 (3), 209-216

[27] Medina, M., (2010) Solid waste, poverty and the environment in developing countries cities: Challenges and opportunities. Working Paper 23, Institute of Advanced Studies, United Nations University,Tokyo, pp: 2.

[28] Mihai FC., (2017) One Global Map but Different Worlds: Worldwide Survey of Human Access to Basic Utilities. Human Ecology 45 (3) 425-429 doi : 10.1007/s10745-017-9904-7

[29] Millicent, A. A., and Ibrahim Y., (2013) Householders' satisfaction towards solid waste collection services of zoomlion ghana ltd in wa, ghana

[30] Modak, P. (2010) Municipal Solid Waste Management: Turning waste into resources. Shanghai Manual - A Guide for Sustainable Urban Development in the 21st Century.

[31] Muderrisoglu, H.; Altanlar, A., (2011) Attitudes and behaviour of undergraduate students toward environmental issues. Int. J. Environ. Sci. Tech., 8 (1), 159-168 (10 pages).National Population Commission, (2006). Final Results, Kwara

[32] Mugenda, O. M., and Mugenda A. G., (1999) Research Methods: Quantitative and Qualitative Approaches. Nairobi: Acts Press.

[33] Muller S M., Iyer A., Keita M., Sacko B. and Traore D. (2002) Differing interpretations of community participation in waste management in Bamako and Bangalore: some methodological considerations

[34] Muniafu, M. and Otiato, E. (2010).Solid Waste Management in Nairobi, Kenya. A case for emerging economies. The Journal of Language, Technology \& Entrepreneurship in Africa, Vol. 2. No.1: 342- 
[35] Muzenda, E, Belaid, M., Mollagee, M., Motampane, N., Ntuli, F., (2011) Reflecting on Waste Management Strategies for South Africa. World Congr Eng Comput Sci 2: 19-21.

[36] Mwesigye, P., Mbogoma, J., Nyakang'o, J. (2009) Africa review report on waste management Main Report.

[37] Ndum, E. (2013) Bottom- Up Approach to Sustainable Solid Waste Management in African Countries. $\mathrm{PhD}$ Thesis, University of Technology, Cottbus

[38] Nema, A., (2009) Report: Risk factors associated with treatment of mixed municipal solid waste in the Indian context. Waste Management \& Research 27: 996-1001.

[39] Obirih-Opareh, N., and Post J., (2002) Quality assessment of public and private modes of solid waste collection in Accra, Ghana. Habitat International 26 pp 95 -112.

[40] Ogu V.i I.,, 2000 Private sector participation and municipal waste management in Benin City, Nigeria

[41] Okot-Okumu, J., and Nyenje. R., (2011) Municipal solid waste management under decentralization in Uganda. Habitat International 35, pp. 537543.

[42] Patel, M.L., Jain, R. and Saxena, A. (2011) Assessment of the Municipal Solid Waste \& Status of Implementation of Municipal Solid Waste (Management \& Handling), Rules, 2000 in the State of Madhya Pradesh, 2008 - A case study. Waste Management \& Research 29: 558-562.

[43] United Cities and Local Governments - UCLG (2013) Basic services for all in an urbanizing world, Third Global Report of United Cities and Local Governments on Local Democracy and Decentralization GOLD III Executive Summary www.uclg.org

[44] Waweru, S. G. 1., and Kanda ,E. K.1., (2012) Municipal Solid Waste Management in Kenya: A Comparison of Middle Income and Slum Areas

[45] World Bank (1991) "Urban policy and economic development: an agenda for the 1990s", World Bank policy paper, Washington DC;

[46] World Bank (1993) "Housing: enabling markets to work", World Bank policy paper, Washington DC.

[47] World Bank Development Report (2004) Making Services Work For Poor People. The World Bank 